Article

\title{
Development of Honeycomb Methanation Catalyst and Its Application in Power to Gas Systems
}

\author{
Philipp Biegger ${ }^{1}$, Florian Kirchbacher ${ }^{2}$, Ana Roza Medved ${ }^{1}$, Martin Miltner ${ }^{2}$ (D), \\ Markus Lehner ${ }^{1, *}$ and Michael Harasek ${ }^{2}$ (D) \\ 1 Montanuniversitaet Leoben, Chair of Process Technology and Industrial Environmental Protection, \\ Franz-Josef-Strasse 18, 8700 Leoben, Austria; philipp.biegger@unileoben.ac.at (P.B.); \\ ana.medved@unileoben.ac.at (A.R.M.) \\ 2 Institute of Chemical, Environmental and Bioscience Engineering, Vienna University of Technology, \\ Getreidemarkt 9/166, 1060 Vienna, Austria; florian.kirchbacher@tuwien.ac.at (F.K.); \\ martin.miltner@tuwien.ac.at (M.M.); michael.harasek@tuwien.ac.at (M.H.) \\ * Correspondence: markus.lehner@unileoben.ac.at; Tel.: +43-(0)3842-402-5001
}

Received: 30 May 2018; Accepted: 20 June 2018; Published: 27 June 2018

\begin{abstract}
Fluctuating energy sources require enhanced energy storage demand, in order to ensure safe energy supply. Power to gas offers a promising pathway for energy storage in existing natural gas infrastructure, if valid regulations are met. To improve interaction between energy supply and storage, a flexible power to gas process is necessary. An innovative multibed methanation concept, based on ceramic honeycomb catalysts combined with polyimide membrane gas upgrading, is presented in this study. Cordierite monoliths are coated with $\gamma-\mathrm{Al}_{2} \mathrm{O}_{3}$ and catalytically active nickel, and used in a two-stage methanation process at different operation conditions ( $p=6-14$ bar, GHSV $=3000-6000 \mathrm{~h}^{-1}$ ). To fulfill the requirements of the Austrian natural gas network, the product gas must achieve a $\mathrm{CH}_{4}$ content of $\geq 96 \mathrm{vol} \%$. Hence, $\mathrm{CH}_{4}$ rich gas from methanation is fed to the subsequent gas upgrading unit, to separate remaining $\mathrm{H}_{2}$ and $\mathrm{CO}_{2}$. In the present study, two different membrane modules were investigated. The results of methanation and gas separation clearly indicate the high potential of the presented process. At preferred operation conditions, target concentration of 96 vol $\% \mathrm{CH}_{4}$ can be achieved.
\end{abstract}

Keywords: power to gas; methanation; membrane gas upgrading; energy storage; honeycomb catalyst

\section{Introduction}

The global efforts to reduce greenhouse gas emissions and decarbonization of power supply cause major changes in all sectors of the energy economy. Since renewables are highly fluctuating, an increasing energy storage demand is predicted [1,2], which is necessary to ensure a secure supply. Generally, a shift from a fossil fuel based economy to an electric energy dominated system is expected. Nevertheless, fuel based networks like the natural gas grid offer enormous storage potential and are also capable of transporting huge amounts of energy. A link between electric and chemical energy could be a promising option to fulfill the requirements of the energy transition.

Power to gas technology can be used to convert electric power to chemical energy for storage. The core technique therein is water electrolysis, responsible for the energy conversion by using electrical power to split water into $\mathrm{H}_{2}$ and $\mathrm{O}_{2}$. In a medium- to long-term perspective, $\mathrm{H}_{2}$ could play a key role in energy supply as it provides beneficial characteristics: first of all, hydrogen is a carbon free fuel and can be used in stationary and mobile applications. Secondly, it can be stored in pressure tanks or underground gas storages in large-scale amounts. Generally, gas networks provide considerably more storage capacity compared to electric power grids. Lastly, the public acceptance for a clean fuel is 
expected to be quite high, which is also an essential property for future applications. On the downside, current energy infrastructure (electricity, mineral oil, natural gas) and customer structure (low demand, small number of customers) is not ready for a hydrogen economy.

Unlike $\mathrm{H}_{2}$, natural gas is widely available with already fully developed infrastructure for transport, storage and utilization. Since $\mathrm{H}_{2}$ and natural gas are gaseous fuels, a blend of those two gases is conceivable. Even higher $\mathrm{H}_{2}$ contents are technically possible, as already demonstrated in town gas applications [3]. A mixture of natural gas and $\mathrm{H}_{2}$ could be the solution for the mentioned structural problems. Although natural gas qualities are regulated on national and international levels, the admixture of small amounts of $\mathrm{H}_{2}(\approx 5 \mathrm{vol} \%)$ to the natural gas is tolerated in central Europe. According to the Austrian regulations [4], up to $4 \mathrm{~mol} \%$ of $\mathrm{H}_{2}$ is allowed, which is compliant with other key figures like heating value, relative gas density and Wobbe index. Higher $\mathrm{H}_{2}$ contents have a significant impact on these key figures and the gas blend would be out of specification. Figure 1 shows the effects of $\mathrm{H}_{2}$ on typical gas key figures, based on natural gas type Russia $\mathrm{H}$ (initial composition in Table 1).

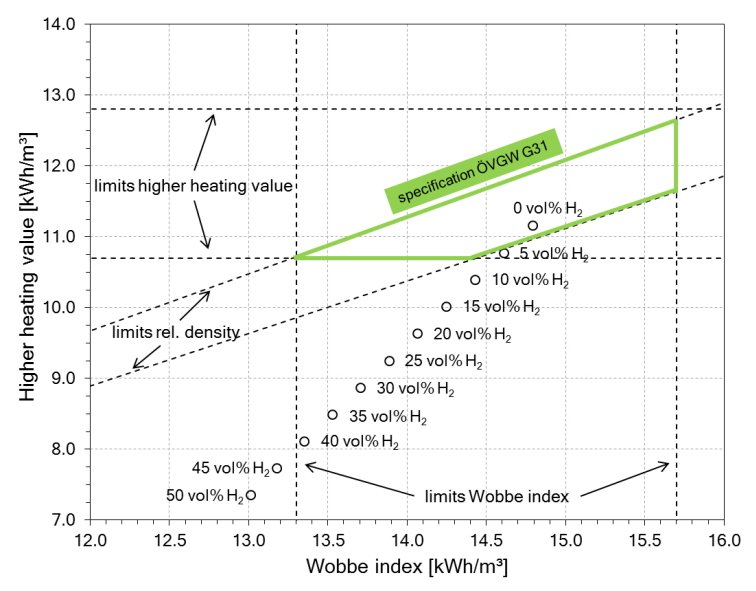

(a)

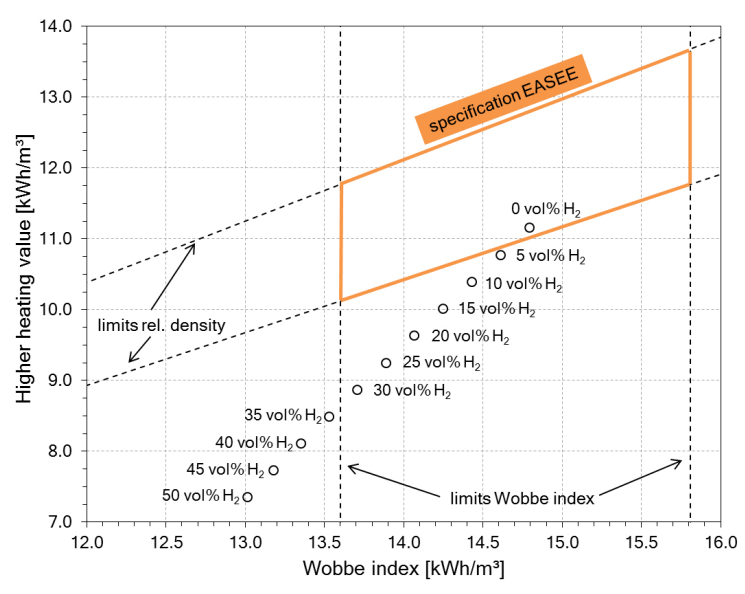

(b)

Figure 1. Impact of $\mathrm{H}_{2}$ on natural gas (Russia $\mathrm{H}$ ) with different regulatory limits; after [5]; (a) specification limits according to Austrian regulations ÖVGW G31 [4]; (b) specification limits according to European regulations EASEE [6].

Table 1. Initial composition and gas properties of natural gas type Russia H.

\begin{tabular}{llr}
\hline Component/Property & Unit & Value \\
\hline methane $\mathrm{CH}_{4}$ & vol \% & 97.79 \\
ethane $\mathrm{C}_{2} \mathrm{H}_{6}$ & vol \% & 0.88 \\
propane $\mathrm{C}_{3} \mathrm{H}_{8}$ & vol \% & 0.29 \\
n-butane $\mathrm{C}_{4} \mathrm{H}_{10}$ & vol \% & 0.10 \\
n-pentane $\mathrm{C}_{5} \mathrm{H}_{12}$ & vol \% & 0.02 \\
n-hexane $\mathrm{C}_{6} \mathrm{H}_{14}$ & vol \% & 0.01 \\
nitrogen $\mathrm{N}_{2}$ & vol \% & 0.82 \\
carbon dioxide $\mathrm{CO}_{2}$ & vol \% & 0.09 \\
hydrogen $\mathrm{H}_{2}$ & vol \% & 0.00 \\
higher heating value $\mathrm{HHV}$ & $\mathrm{kWh} / \mathrm{m}^{3}$ & 11.16 \\
Wobbe index & $\mathrm{kWh} / \mathrm{m}^{3}$ & 14.79 \\
relative density & - & 0.57 \\
\hline
\end{tabular}

To circumvent the present structural problems of $\mathrm{H}_{2}$, an additional process step, methanation, can be used, where $\mathrm{H}_{2}$ is combined with $\mathrm{CO}$ and/or $\mathrm{CO}_{2}$ to form $\mathrm{CH}_{4}$ and $\mathrm{H}_{2} \mathrm{O}$. The underlying Sabatier reactions are given in Equations (1) and (2): 


$$
\begin{aligned}
\mathrm{CO}_{(\mathrm{g})}+3 \mathrm{H}_{2(\mathrm{~g})} & \rightleftharpoons \mathrm{CH}_{4(\mathrm{~g})}+\mathrm{H}_{2} \mathrm{O}_{(\mathrm{g})} \Delta H_{r}^{0}=-206 \mathrm{~kJ} / \mathrm{mol} \Delta G^{0}=-142 \mathrm{~kJ} / \mathrm{mol}, \\
\mathrm{CO}_{2(\mathrm{~g})}+4 \mathrm{H}_{2(\mathrm{~g})} & \rightleftharpoons \mathrm{CH}_{4(\mathrm{~g})}+2 \mathrm{H}_{2} \mathrm{O}_{(\mathrm{g})} \Delta H_{r}^{0}=-165 \mathrm{~kJ} / \mathrm{mol} \Delta G^{0}=-114 \mathrm{~kJ} / \mathrm{mol} .
\end{aligned}
$$

The methanation of $\mathrm{CO}$ (Equation (1)) and $\mathrm{CO}_{2}$ (Equation (2)) are linked via the reverse water-gas shift reaction in Equation (3):

$$
\mathrm{CO}_{2(\mathrm{~g})}+\mathrm{H}_{2(\mathrm{~g})} \rightleftharpoons \mathrm{CO}(\mathrm{g})+\mathrm{H}_{2} \mathrm{O}_{(\mathrm{g})} \Delta H_{r}^{0}=41 \mathrm{~kJ} / \mathrm{mol} \Delta G^{0}=29 \mathrm{~kJ} / \mathrm{mol} .
$$

The Sabatier process and the water-gas shift reaction are catalyzed by metals of IUPAC (International Union of Pure and Applied Chemistry) groups 8 to 10. Usually, nickel based catalysts are the preferred choice due to their high catalytic activity, high $\mathrm{CH}_{4}$ selectivity and comparably low costs [7]. Regarding process design, three basic concepts were developed:

- fixed bed methanation (bulk and honeycomb catalysts),

- fluidized bed methanation, and

- three phase methanation.

On a commercial scale, fixed bed processes are dominating [8,9] and are offered by different companies [10]. Besides power to gas applications, fixed bed methanation is a state-of-the-art technology for gas cleaning units e.g., in ammonia plants [9]. As seen in Equations (1) and (2), the reactions are highly exothermic, thus appropriate heat management of the reactors is very important. Various reactor concepts including product gas recycle as well as internal and external heat exchangers were developed $[9,10]$.

The present study deals with the combination of catalytic methanation and membrane based gas upgrading in a proof of concept. Each process unit includes innovative approaches to fit the requirements of a fluctuating energy storage application. While methanation is using a ceramic honeycomb as a substrate for the nickel catalyst, gas upgrading is done with tailored polyimide membranes for high methane selectivities. On the one hand, the used setup should demonstrate the function of honeycomb methanation catalysts and the membrane gas upgrading by fulfillment of local natural gas quality regulations. On the other hand, impact of operation parameters like pressure level and space velocity on process control and product gas composition are determined.

High methane concentrations in the product gas are achieved by catalytic methanation only under stable process conditions. If methanation is going to be used for power to gas systems on a large scale, product quality needs to be ensured for changing process conditions, making additional gas upgrading necessary.

Besides steam, which is easily condensable, the main impurities remaining after methanation are $\mathrm{H}_{2}$ and $\mathrm{CO}_{2}$. For $\mathrm{CO}_{2}$ removal from $\mathrm{CH}_{4}$, various options are commercially available for biogas upgrading. Most commonly used are (according to [11]):

- $\quad$ water scrubbing (market share approx. $40 \%$ ),

- physical absorption (market share approx. $6 \%$ ),

- chemical absorption (market share approx. 25\%),

- pressure swing adsorption (market share approx. $25 \%$ ), and

- membranes (market share approx. $4 \%$ )

Water scrubbing is based on the comparatively low solubility of $\mathrm{CH}_{4}$ in water. It uses relatively large reactor volumes and needs high quantities of water, even if water is recycled. The process is normally operated in a range of 6-10 bar [12]. One advantage of the process is that it can deal with $\mathrm{H}_{2} \mathrm{~S}$ impurities, as $\mathrm{H}_{2} \mathrm{~S}$ is absorbed into water [12]. Regeneration is done in a second column by contacting with air. Negative is the potential introduction of $\mathrm{N}_{2}$ and $\mathrm{O}_{2}$ into the process chain during the desorption step [13]. To reduce costs, treated water can be used for the process instead of fresh water, but it aids microbial growth [12]. 
A similar option is physical absorption in polyethylene glycol and its derivates. They offer higher solubility for $\mathrm{CO}_{2}$ and need therefore smaller vessels than water scrubbing [14]. Regeneration is performed at elevated temperatures of $55-80{ }^{\circ} \mathrm{C}$ [13]. Opinions on whether $\mathrm{H}_{2} \mathrm{~S}$ removal is necessary differ $[12,14]$ but is generally done prior to physical absorption [12].

Chemical absorption offers a highly selective option for $\mathrm{CO}_{2}$ removal. In this case, alcanol amines like methyldiethanol amine (MDEA) are used as absorbents. While high selectivity leads to reduced $\mathrm{CH}_{4}$ losses, regeneration needs to be done at temperatures of $120-150{ }^{\circ} \mathrm{C}$ [13]. This decreases the process competitiveness compared to the alternatives, as parts of the product $\mathrm{CH}_{4}$ must be used for heat generation [15]. Other disadvantages are the need of desulfurization [12] and increased corrosion and chemical consumption, due to oxidative degeneration of amine solution [13].

Pressure swing adsorption is based on a combination of molecular size exclusion and adsorption affinity [12]. Commonly used adsorbents are zeolites, silica gels and carbon molecular sieves [13]. Set-up of the process is complex, demanding at least four columns operated in parallel for pressurization, adsorption at 6-10 bar, depressurization and desorption at ambient pressure [12]. However, advantageous are low power demand as well as low emissions [16]. Except for the necessity of prior $\mathrm{H}_{2} \mathrm{~S}$ removal [14], no additional costs for water make-up or heat for regeneration occur [12].

The last option of commercially available upgrading techniques is membrane gas separation, based on differing permeability for components through membrane materials. Most common materials used for natural gas cleaning include polyimides and cellulose acetate membranes, as they offer good selectivity for $\mathrm{CO}_{2} / \mathrm{CH}_{4}$ [17]. Operating pressure is in the range of 5-30 bar to ensure sufficient $\mathrm{CH}_{4}$ enrichment. While membrane based gas upgrading offers low cost, high energy efficency, easy process as well as excellent reliability [16], it has been criticized for lower $\mathrm{CH}_{4}$ recoveries compared to the other options. This trade-off between product purity and recovery can be circumvented by a multistage layout [17]. An improvement of $\mathrm{CH}_{4}$ recovery from $80 \%$ for a one-stage process to $99.5 \%$ has been reported [13] but also leads to a higher specific energy demand [18].

Regarding achievable product purity, all processes are able to achieve concentrations higher than 96 vol \% $\mathrm{CH}_{4}$ with $\mathrm{CH}_{4}$ losses of less than $2 \%$ [12] and are able to meet common gas grid standards. Costs are reported to be ranging from $0.15 € / \mathrm{m}^{3}$ to $0.25 € / \mathrm{m}^{3}$ depending on plant size, with costs favoring membranes and chemical absorption for smaller plants up to $1000 \mathrm{~m}^{3}$ and water scrubbing for larger capacities [13]. This is also supported by the number of realized plants [11].

\section{Innovation}

Originally, methanation processes were developed for syngas applications to produce SNG (Synthetic Natual Gas) from coal [9]. These plants are designed for long-term steady state operation with defined feed gas compositions. The requirements for a power to gas process differ quite considerably. Due to the fluctuating supply of $\mathrm{H}_{2}$, gas storage is often necessary, which can be avoided by load flexible operation as well as good start up and stand by behavior. Besides large scale plants, also smaller, decentralized power to gas units are possible. Depending on the carbon source, impurities like sulfur compounds must be expected. Therefore, tailored gas cleaning devices are also part of the system.

To improve load flexibility, stand-by and response characteristics, a new methanation concept based on washcoated honeycomb catalysts was developed. Monolithic honeycombs consist of ceramic or metallic blocks with channels of different shapes (square, triangular, hexagonal). They have been in use for decades and standard in automotive applications [19]. Often honeycombs are just a carrier structure for the catalytic material, which has to be applied via coating. Structured catalysts offer several advantages like low pressure drop, simplified scalability, homogeneous flow and low axial mixing [20,21]. Adverse effects are limited heat transport, hindered temperature control, smaller geometric surface compared to bulk catalysts and costly production $[20,21]$.

Ceramic monoliths are used in heat recovery applications, due to their low thermal expansion, thermal conduction and high thermal shock resistance. These properties can also be advantageous in a 
methanation process. For nickel catalysts, it is necessary to achieve a minimum reaction temperature of $200{ }^{\circ} \mathrm{C}$ to avoid the formation of toxic $\left[\mathrm{Ni}(\mathrm{CO})_{4}\right]$. To reduce trace heating during stand-by, the heat of reaction can be stored by the honeycombs. Furthermore, a multi bed reactor concept with additional chambers in each stage should support heat storage and operation flexibility.

Multi bed reactors are commonly used in applications where thermodynamics or reaction kinetics require temperature restrictions. Therefore, the reactor is divided in two or more stages, which can be cooled directly or indirectly. Furthermore, gas recycles and fresh gas injections are possible. A well-known application of multi bed reactors is the Haber-Bosch process [22]. Compared to a series of single reactors, heat losses are lower, although much more complex.

The proposed multi bed reactor process is designed with three beds and up to four chambers per stage. While the beds support a controlled heat build-up, the chambers are responsible for high load flexibility. At $100 \%$ load, all chambers are equally used, and each catalyst bed is operated at its design point. By locking individual chambers, the operating window is lowered, e.g., $50 \%$ load for $50 \%$ used chambers. Additionally, the catalysts themselves have an operating range. Consequently, very low capacities can be reached (one of four chambers with a catalyst operating at $50 \%$ results in $12.5 \%$ total load). For quick response of the reactor system, all chambers and beds must be kept on stand-by temperatures above $200{ }^{\circ} \mathrm{C}$. Besides catalytic function, honeycomb is used as heat storage inside the vessel, since heat of reaction is stored in ceramic monoliths. This can also be achieved during operation at low capacities, by cyclical switching between chambers. A schematic illustration of the reactor concept can be seen in Figure 2.

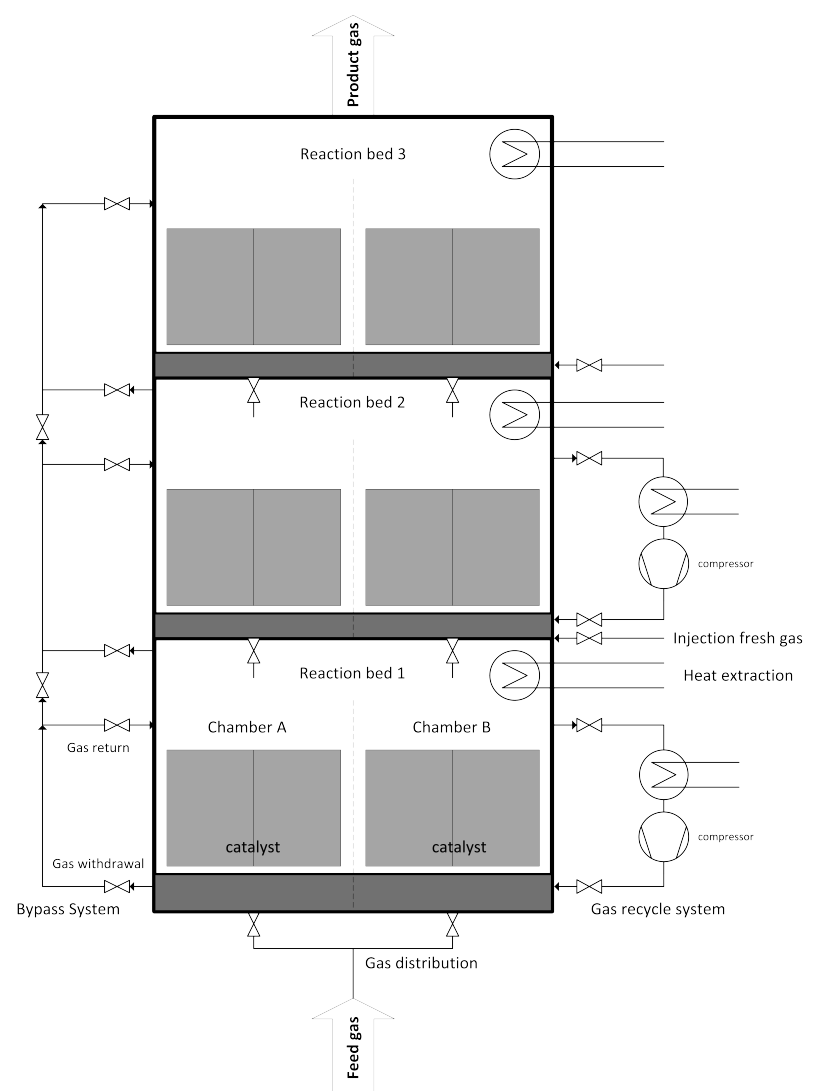

(a)

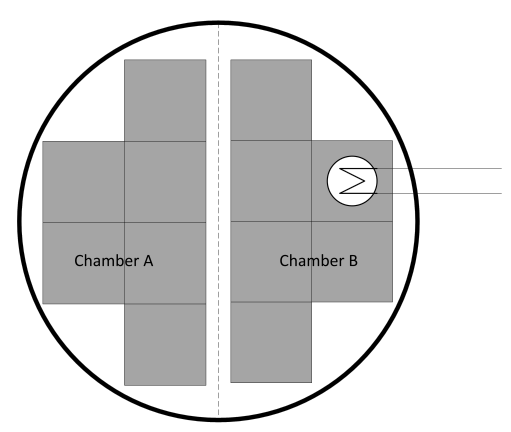

Figure 2. Simplified scheme of a multi bed reactor with three beds and two chambers [23]; (a) elevation; (b) floor plan. 
This load flexibility in the methanation step demands an equally flexible gas upgrading system. The gas upgrading needs to have a fast response rate, being able to handle a large bandwidth of flow rates and also deal with varying gas compositions. Membrane systems in general are highly flexible regarding changing flow rates by adapting the available membrane area due to their modular design [24] and have virtually no response time. Changing composition of the main compounds $\mathrm{H}_{2}, \mathrm{CO}_{2}, \mathrm{CH}_{4}$ and $\mathrm{H}_{2} \mathrm{O}$ due to varying conditions in the methanation can be addressed by the use of polyimide hollow fiber membranes. Polyimide offers a high selectivity for both $\mathrm{H}_{2} / \mathrm{CH}_{4}$ and $\mathrm{CO}_{2} / \mathrm{CH}_{4}$ [25] as well as $\mathrm{H}_{2} \mathrm{O} / \mathrm{CH}_{4}$. This is one of the main advantages compared to the other gas upgrading systems presented as it allows simultaneous removal of $\mathrm{CO}_{2}$ and $\mathrm{H}_{2}$, whereas water scrubbing, chemical absorption and adsorption can only remove $\mathrm{CO}_{2}$. Negative is the potentially large loss of $\mathrm{CH}_{4}$ to the off-gas. To circumvent this problem, the off-gas could be compressed and directly recycled to the methanation, while improving the overall conversion of $\mathrm{CO}_{2}$ and $\mathrm{H}_{2}$ by negating any losses of $\mathrm{CO}_{2}$ and $\mathrm{H}_{2}$ [17]. This is possible because the process is purely physical and neither $\mathrm{H}_{2}$ nor $\mathrm{CH}_{4}$ are chemically transformed. Furthermore, the process setup itself, consisting mainly of a compressor and membrane modules, is rather simple compared to a cyclical process like adsorption leading to relatively low costs. For the injection into the natural gas grid, it is also beneficial that the product stream is already at an elevated pressure level reducing compressor cost to meet injection pressure. A combination of catalytic methanation using a honeycomb structured catalyst and membrane based gas upgrading has yet not been demonstrated, but offers a very promising concept for a highly load flexible power to gas pathway.

\section{Results}

As known from previous investigations of catalytic methanation [26-28], there is a strong dependency of $\mathrm{CO}_{2}$ conversion on GHSV (gas hourly space velocity) and pressure level. For best results, high pressures and low space velocities are preferred. Of course, the number of reaction stages is also important. This behavior was also observed in the current experiments, which were conducted with an undiluted, stoichiometric mixture of $\mathrm{H}_{2}: \mathrm{CO}_{2}=4.0$. Results are shown in Figure 3 . The left $y$-axis represents the dry $\mathrm{CH}_{4}$ content after a particular methanation reactor (MR). Additionally, the right $y$-axis shows the reactor temperature, which was measured directly below (gas entrance) the honeycomb catalyst. At 6 bar, the catalytic methanation achieves comparably poor results, but with a low space velocity of $3000 \mathrm{~h}^{-1}$ even $58.7 \mathrm{vol} \% \mathrm{CH}_{4}$ is possible. It also can be seen that the $\mathrm{CH}_{4}$ content is nearly doubled in the second reactor stage. According to earlier experiments [26-28], conversion rates are decreasing with increasing space velocity. To improve conversion rate and consequently $\mathrm{CH}_{4}$ level of the product gas, the system pressure needs to be adjusted to higher values. The impact of 10 and 14 bar compared to 6 bar is also depicted in Figure 3. While 10 bar leads to an increase of approx. $5 \mathrm{vol} \% \mathrm{CH}_{4}$, a system pressure of 14 bar allows for an improvement of $\geq 10 \mathrm{vol} \% \mathrm{CH}_{4}$ after reactor 2 (R2). Due to the arrangement of the temperature sensors and the high heat losses of the vessel, the reactor temperature remains quite constant between 350 and $380^{\circ} \mathrm{C}$ for $\mathrm{R} 1$ and $300-320{ }^{\circ} \mathrm{C}$ for $\mathrm{R} 2$.

Figure 4 shows the results obtained by gas separation unit (GSU) in the combined process. The presented feed composition (MR) differs from results in Figure 3 (R2), which is caused by the experimental setup. Since both test plants are originally designed for stand-alone operation, they use separate gas analyzers. Furthermore, data cannot be collected simultaneously, due to the impact of gas sampling on downstream processes. Consequently, values are measured at different dates, process conditions deviate slightly and $\mathrm{CH}_{4}$ content is varying. Results for module 1 can be seen in Figure 4a. Most importantly, the targeted product gas quality of $96 \mathrm{vol} \% \mathrm{CH}_{4}$-to comply with Austrian natural gas regulations-can be accomplished, but only for the lowest GHSV of $3000 \mathrm{~h}^{-1}$ and the highest pressure level of 14 bar. At 6 bar, $\mathrm{CH}_{4}$ concentration increases by around $25 \mathrm{vol} \%$ independent of GHSV. Elevated pressure levels show an improved increase in $\mathrm{CH}_{4}$ concentration from $30 \mathrm{vol} \%$ $\left(G H S V=3000 \mathrm{~h}^{-1}\right)$ to $40 \mathrm{vol} \%\left(G H S V=3000 \mathrm{~h}^{-1}\right)$ at $10 \mathrm{bar}$ and from $30 \mathrm{vol} \%\left(G H S V=3000 \mathrm{~h}^{-1}\right)$ to $45 \mathrm{vol} \%\left(G H S V=3000 \mathrm{~h}^{-1}\right)$ at 14 bar. Module 2, with results depicted in Figure $4 \mathrm{~b}$, shows a very 
different picture. For the same set of inlet concentrations from methanation, the targeted product specification is achieved at 6 bar at GHSVs $3000 \mathrm{~h}^{-1}$ and $4000 \mathrm{~h}^{-1}$ and for all experiments conducted at 10 bar. An experimental assesment of module 2 at 14 bar was not possible, due to the module's high permeances compared to module 1. Figure 5 represents $\mathrm{CH}_{4}$ recovery (see Equation (4)) on the $y$-axis versus stage cut (see Equation (5)) on the $x$-axis. The semi-filled markers indicate experiments that fulfilled the target $\mathrm{CH}_{4}$ concentration:

$$
\begin{gathered}
\text { Recovery }_{\mathrm{GSU}_{\mathrm{CH}}}(-)=\frac{\dot{V}_{\mathrm{GSU}, \mathrm{CH}}, \text { Product }_{4}\left(\mathrm{~m}^{3} \mathrm{STP} / \mathrm{h}\right)}{\dot{V}_{\mathrm{GSU}, \mathrm{CH}_{4}, \text { Feed }}\left(\mathrm{m}^{3} \mathrm{STP} / \mathrm{h}\right)}, \\
\text { Stage Cut }(-)=\frac{\dot{V}_{\mathrm{GSU}, \text { Off-gas }}\left(\mathrm{m}^{3} \mathrm{STP} / \mathrm{h}\right)}{\dot{V}_{\mathrm{GSU}, \text { Feed }}\left(\mathrm{m}^{3} \mathrm{STP} / \mathrm{h}\right)} .
\end{gathered}
$$

All experiments for module 1 showed an extremely high $\mathrm{CH}_{4}$ recovery of at least 0.85 and therefore little $\mathrm{CH}_{4}$ losses to the off-gas with comparatively low stage cuts ranging from 0.3 to 0.5 indicating a low off-gas flow rate. While module 2 showed more promising results regarding product gas $\mathrm{CH}_{4}$ concentration, recovery is low dropping down as far as 0.19 with high stage cuts between 0.7 and 0.9 .

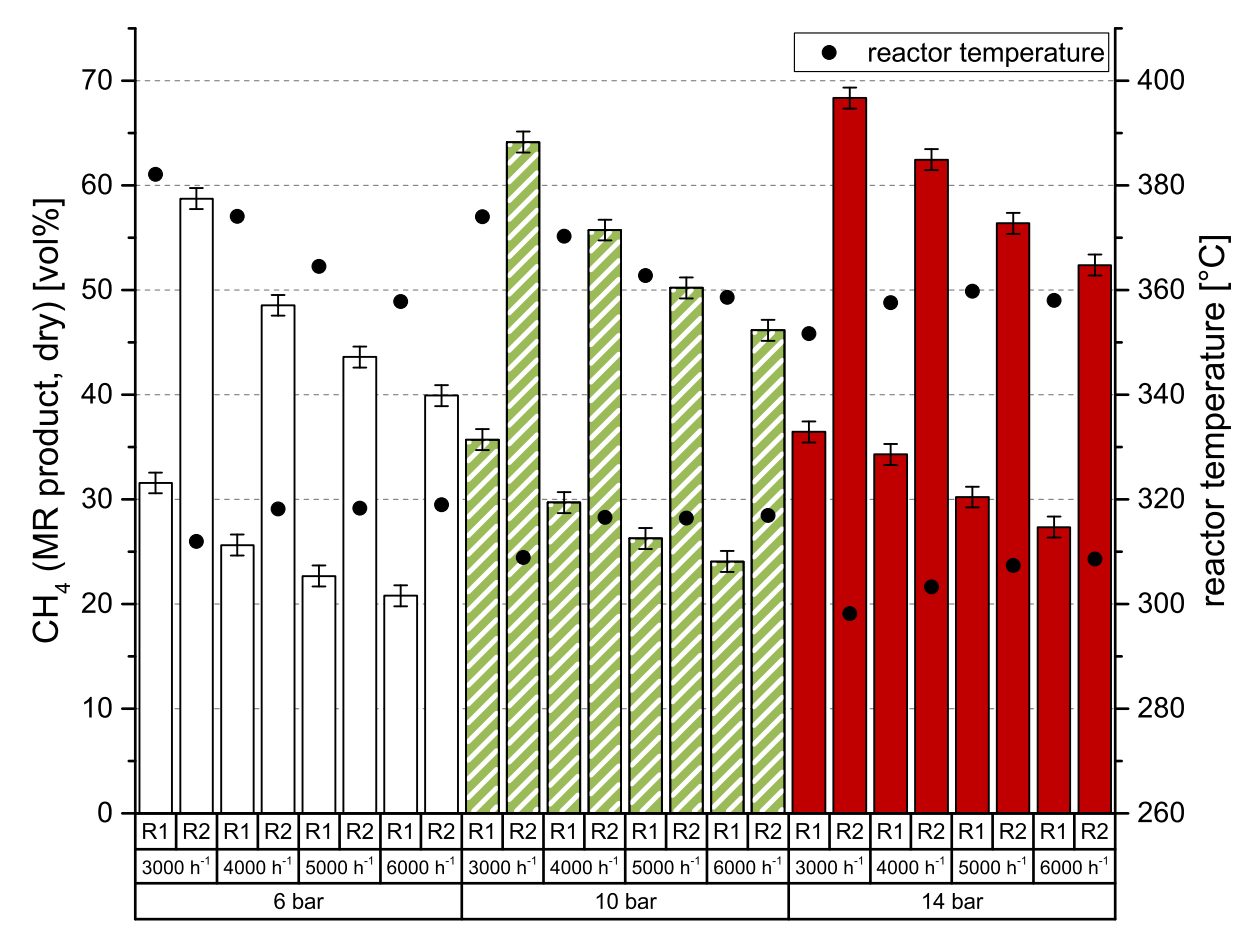

Figure 3. Two-stage methanation of $\mathrm{H}_{2}: \mathrm{CO}_{2}=4.0$ over $\mathrm{GHSV}\left(\mathrm{h}^{-1}\right)$ and system pressure; catalyst: ceramic honeycomb, $\mathrm{Ni} / \gamma-\mathrm{Al}_{2} \mathrm{O}_{3}, 50 \times 50 \times 142 \mathrm{~mm}, 300 \mathrm{cpsi}$; (MR: methanation reactor). 


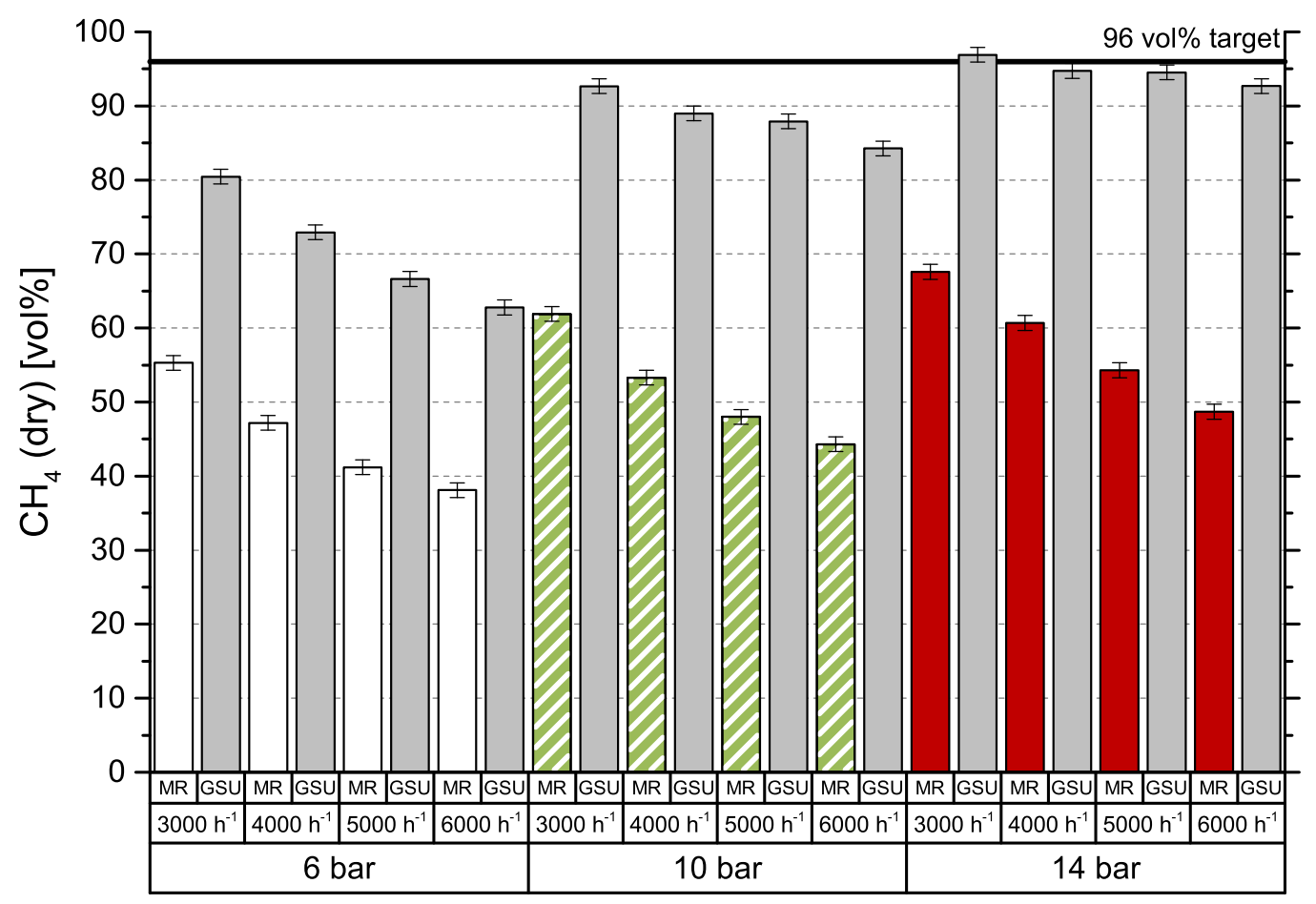

(a)

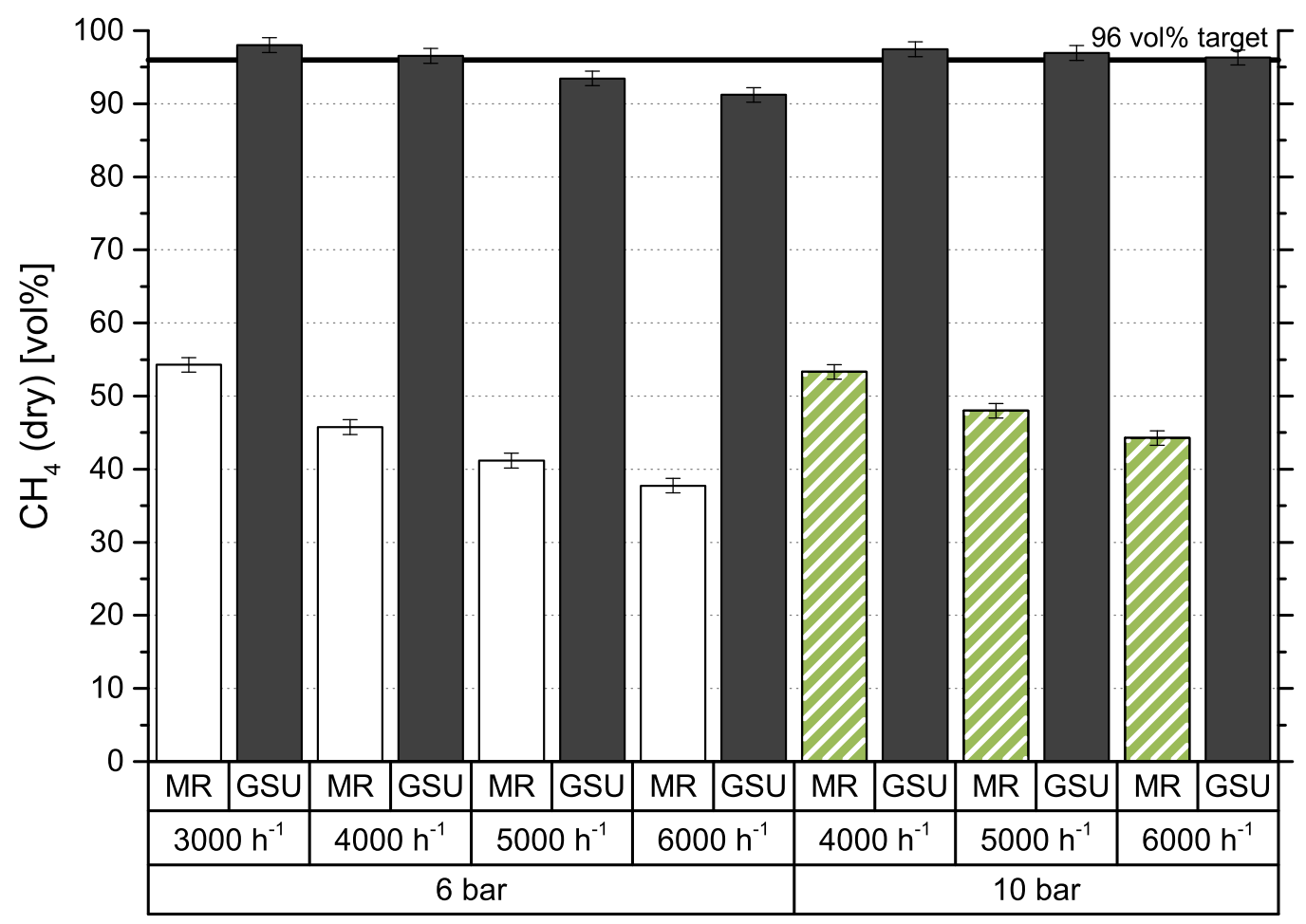

(b)

Figure 4. Concentration of $\mathrm{CH}_{4}$ in feed gas (MR) and product gas (GSU) for different modules; (a) Module 1; (b) Module 2. 


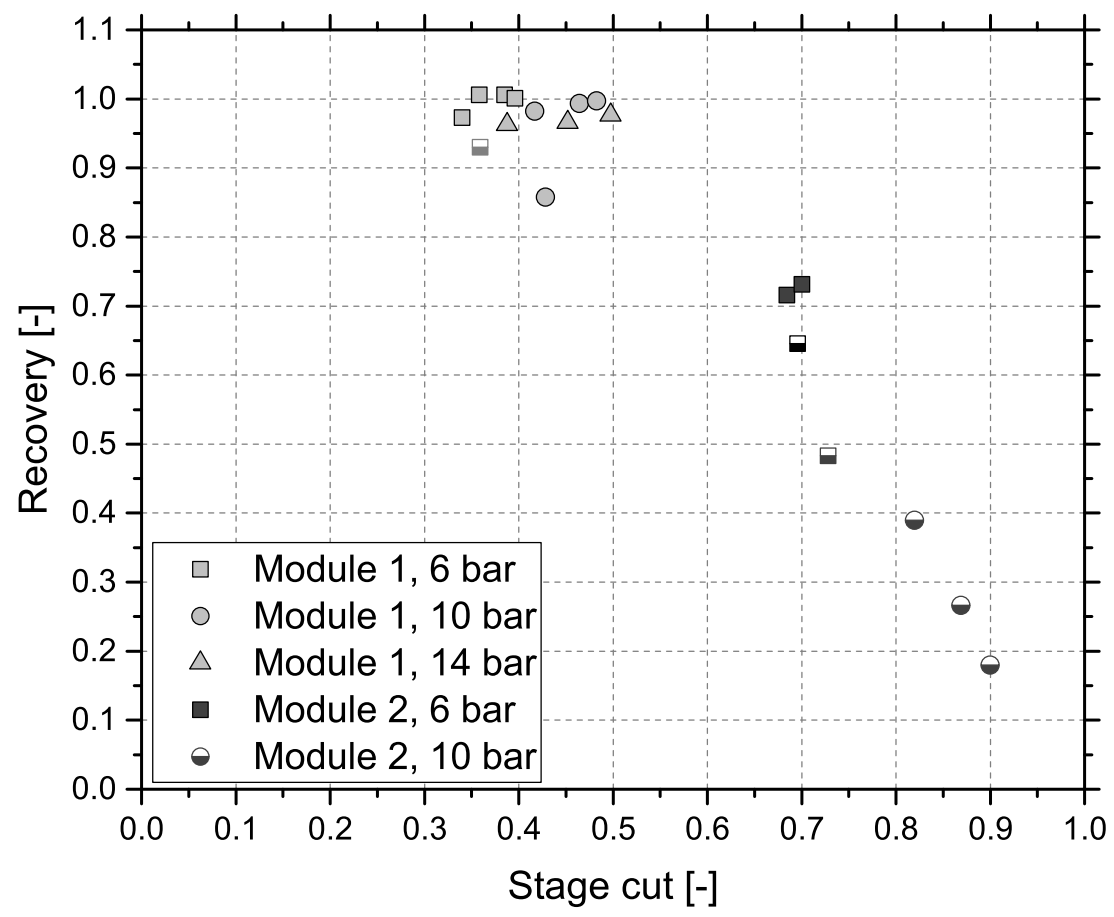

Figure 5. Recovery of $\mathrm{CH}_{4}$ vs. stage cut for both modules; successful experiments $\geq 96$ vol $\% \mathrm{CH}_{4}$ identified with semi-filled markers.

\section{Discussion}

The honeycomb catalyst is in its early development stage, thus its full potential has not been used yet. Besides geometrical parameters like length, channel number and channel width, the coating process also needs further improvements. Basically, the honeycomb catalyst works stable, reliable and behaves like a commercial bulk catalyst. Compared with bulk catalyst Meth $134^{\circledR}$, the commercial product shows higher catalytic activity, which consequently causes increased conversion rate and reactor temperature [29]. Nonetheless, the methanation results are promising and prospects for further development is good.

Basically, test plants often have to deal with issues caused by their size, since surface:volume ratios of vessels and pipes are much higher than in pilot scale, which is also occurring in the present case. Due to reactor design specifications $\left(750^{\circ} \mathrm{C}, 21 \mathrm{bar}\right)$, vessels of the utilized test plant are very heavy with a single weight of $190 \mathrm{~kg}$. Besides its poor handling, heat losses are high. Despite insulation and exothermic methanation reaction, vessels need to be heated during experiments. Furthermore, the structure of honeycomb catalysts does not allow temperature measurement inside channels, resulting in lower registered temperatures than expected peak reaction temperatures. These properties and placing of thermocouples are causing distorted temperature measurement and management. To overcome the aforementioned issues, new custom pressure vessels with drastically reduced weight (12.5 kg at comparable volume) were installed. First experiments prove the estimated improvement, since reactor temperatures are higher and heat losses are lower. Consequently, conversion rates are decreasing.

Results presented for the combined approach of methanation and membrane based upgrading proved to be very promising and the effects of different membrane modules are clearly apparent. Module 1 is able to achieve the necessary product gas quality only under the most favorable conditions, low GHSV combined with high pressure. Data (see Figure 4a) obtained at 6 bar show a constant improvement of $25 \mathrm{vol} \% \mathrm{CH}_{4}$ due to the upgrading step. Results at 14 bar show a drop of $4 \mathrm{vol} \% \mathrm{CH}_{4}$ 
due to GHSV after the GSU while the methanation step dropped considerably from 68 vol $\% \mathrm{CH}_{4}$ to $49 \mathrm{vol} \% \mathrm{CH}_{4}$. This indicates that the role of GHSV is secondary compared to the pressure for the gas upgrading step. Data from module 2 (see Figure $4 \mathrm{~b}$ ) show some important differences. Although selectivities are lower, product quality can be achieved at lower pressure levels and/or higher GHSVs due to the higher module permeances. The trade-off is a much higher stage cut-at least 0.7 instead of approx. $0.4-$ and reduced recovery- -65 compared to approx. 0.95 . Furthermore, it was not possible to operate module 2 at GHSV $=3000 \mathrm{~h}^{-1}$ and $10 \mathrm{bar}$ as well as at $14 \mathrm{bar}$ in general. The reason for this is that the stage cut for this operating conditions approached 1 and the necessary pressure could not be kept constant.

This leads to the following conclusions for the use in a power to gas concept. A load flexible honeycomb catalyst can be used in combination with a single-stage membrane GSU to produce SNG in compliance with common gas grid standards. A highly selective membrane module with a well designed membrane area would be able to achieve this at higher pressure levels and low GHSVs with a $\mathrm{CH}_{4}$ recovery above $90 \%$ but would fail outside this narrow operation window. Furthermore, stage cut would still be around 0.35 , meaning that $35 \%$ of the total volume flow consisting mainly of $\mathrm{CO}_{2}$ and $\mathrm{H}_{2}$ would be lost to the off-gas. Installing additional membrane modules in parallel would allow for adapting this system to the process's needs, but would also increase the capital costs. Using a membrane that offers higher transmembrane fluxes but has a lower selectivity means that less modules are needed for operation in comparable conditions and it appears to be more flexible regarding pressure and GHSV. However, this would also increase off-gas flowrate, decrease recovery and therefore lower overall efficiency. To prevent this, a recycle of the off-gas to the methanation reactor has to be included in this scenario. Implementation of a two-stage membrane setup is an additional opportunity for improvement, since it would enhance recovery rate and balance fluctuations in catalytic methanation.

\section{Materials and Methods}

\subsection{Ceramic Honeycomb Catalyst}

The ceramic honeycomb catalyts consist of cordierite $\mathrm{Mg}_{2} \mathrm{Al}_{3}\left[\mathrm{AlSi}_{5} \mathrm{O}_{18}\right]$. Compared to other substrate materials, ceramic honeycombs offer large pores and low specific surface areas of approx. $0.3 \mathrm{~m}^{2} / \mathrm{g}$. To provide the needed surface area of $>100 \mathrm{~m}^{2} / \mathrm{g}$ the carrier material is coated with inorganic oxides like $\gamma-\mathrm{Al}_{2} \mathrm{O}_{3}$ or $3 \% \mathrm{Y}_{2} \mathrm{O}_{3}$-stabilized $\mathrm{ZrO}_{2}\left(\mathrm{t}-\mathrm{ZrO}_{2}\right)$. In a subsequent dip coating step, the catalytic active material $\mathrm{Ni}$ is applied. Figure $6 \mathrm{~b}$ illustrates the coating process for nickel $/ \gamma-\mathrm{Al}_{2} \mathrm{O}_{3}$ catalysts on cordierite support (Figure 6a), developed by Fuchsbauer et al. [30]. In a first step, $38.4 \mathrm{~g}$ boehmite powder $\gamma$ - $\mathrm{AlO}(\mathrm{OH})$ and $60.0 \mathrm{~g}$ binding agent $(8.2 \mathrm{~m} \%$ Mowital $830 \mathrm{H}$ in ethanol) are mixed, followed by dip coating of the ceramic honeycomb. After drying and calcination at $600{ }^{\circ} \mathrm{C}$, the catalytically active layer is applied by dip coating $20 \mathrm{~m} \% \mathrm{Ni}\left(\mathrm{NO}_{3}\right)_{2} \cdot 6 \mathrm{H}_{2} \mathrm{O}$. Finally, the coated monolith is dried to constant mass and is ready for activation in the reactor. The catalyst activation was conducted with a defined $\mathrm{N}_{2}: \mathrm{H}_{2}$ ratio and a temperature of $300 \pm 15{ }^{\circ} \mathrm{C}$. Figure 7 shows the activation process of both reactors at ambient pressure.

For the current experiments, a honeycomb with square channels was used (Figure 6a). Its dimensions were $A \times B \times H=50 \mathrm{~mm} \times 50 \mathrm{~mm} \times 142 \mathrm{~mm}$ with a cell density of $300 \mathrm{cpsi}$ (channels per square inch). More details about catalyst geometry and coating can be found in Table 2 . The two catalysts were applied during all experimental runs.

A common value to compare catalyst load is gas hourly space velocity, GHSV. It is calculated by the quotient of volumetric flow rate (STP) and catalyst volume (Equation (6)). The higher the space velocity, the higher the catalyst stress. Since the flow rate is considered at standard conditions, the influence of system pressure is not described by GHSV. During the experiments, space velocities in the range of $3000 \mathrm{~h}^{-1}$ to $6000 \mathrm{~h}^{-1}$ were used: 


$$
\operatorname{GHSV}\left(\mathrm{h}^{-1}\right)=\frac{\dot{V}_{\text {Gas }}\left(\mathrm{m}^{3} \text { STP } / \mathrm{h}\right)}{V_{\text {Catalyst }}\left(\mathrm{m}^{3}\right)}
$$

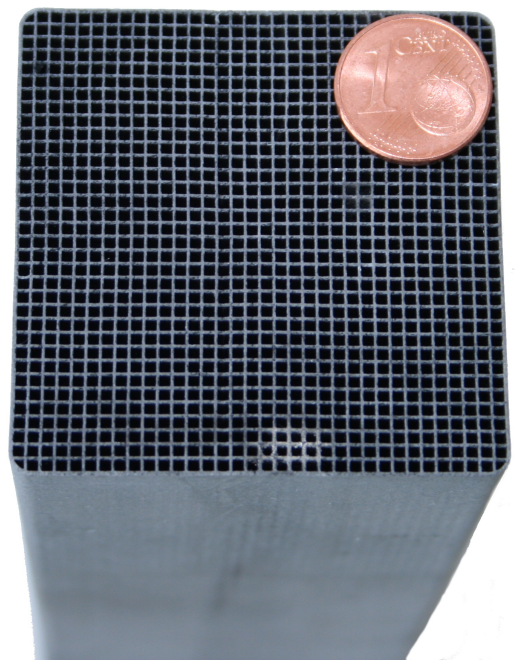

(a)

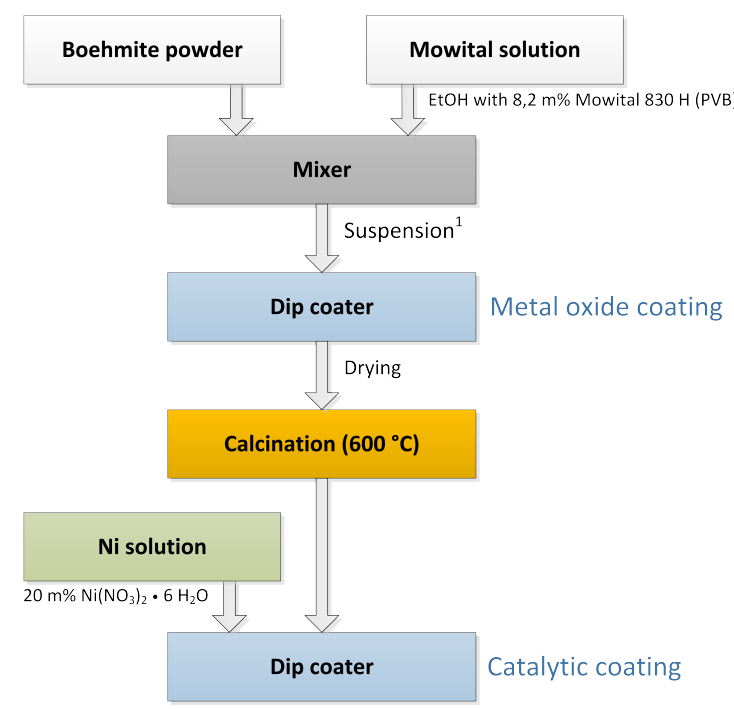

(b)

Figure 6. Example of honeycomb catalyst in lab scale and its coating process; (a) Honeycomb catalyst. $A \times B \times H=50 \times 50 \times 142 \mathrm{~mm}$, cell density = $300 \mathrm{cpsi}$; (b) Coating process of ceramic honeycombs [30]; ${ }^{1}$ Suspension: $60.0 \mathrm{~g}$ Mowital solution, $34.8 \mathrm{~g}$ Boehmite.

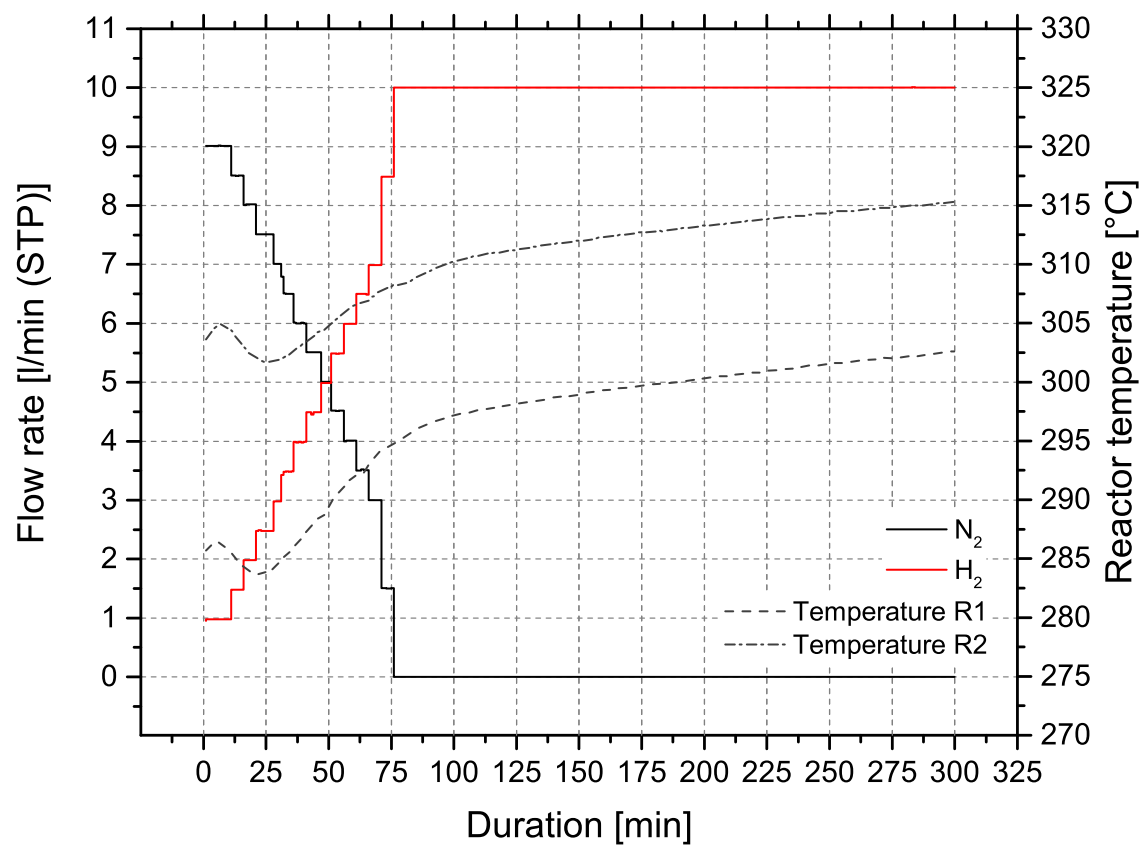

Figure 7. Activation process of honeycomb catalysts in reactors $\mathrm{R} 1$ and $\mathrm{R} 2, p=1-2$ bar. 
Table 2. Properties of the honeycomb catalyst.

\begin{tabular}{lcl}
\hline Property & Unit & Value \\
\hline cell form & - & square \\
$A, B$ & $\mathrm{~mm}$ & $50 \pm 1$ \\
$H$ & $\mathrm{~mm}$ & $142 \pm 1$ \\
cell spacing $L$ & $\mathrm{~mm}$ & $1.47 \pm 0.025$ \\
wall thickness $t$ & $\mathrm{~mm}$ & $0.30 \pm 0.05$ \\
$V_{\text {Kat }}$ & $\mathrm{dm}^{3}$ & $0.355 \pm 0.018$ \\
cell density $n$ & $\mathrm{cpsi}$ & $300 \pm 5$ \\
total cell number $N$ & - & $1162 \pm 65.9$ \\
porosity $\epsilon$ & - & $0.63 \pm 0.29$ \\
$\gamma-\mathrm{Al}_{2} \mathrm{O}_{3}$ coating & $\mathrm{g}$ & $7.4(\mathrm{R} 1), 7.7(\mathrm{R} 2)$ \\
$\left.\mathrm{Ni} \mathrm{NO}_{3}\right)_{2} \cdot 6 \mathrm{H}_{2} \mathrm{O}$ coating & $\mathrm{g}$ & $24.0(\mathrm{R} 1), 19.2(\mathrm{R} 2)$ \\
\hline
\end{tabular}

\subsection{Lab Scaled Methanation Test Plant}

To investigate the behavior of the structured catalysts, a lab scaled test plant was used. Contrary to the planned multi bed reactor (see Figure 2), it consists of separate reactors. Due to the complexity of staged reactor systems, an implementation on a lab scale was dismissed. Similar to the proposed methanation process, the test plant includes up to three reactors, which can be operated separately or in series. Each reactor is filled with $100 \mathrm{~mm}$ of HiDur ${ }^{\mathrm{TM}}$ stoneware balls (RVTPE, Steinwiesen, Germany) 3/8", in order to ensure an even flow through the catalyst, which is placed on top of the packed bed. Clearance between catalyst and reactor wall is filled with compacted insulation material (mineral wool). Furthermore, two type $\mathrm{K}$ thermocouples are installed inside the reactor to measure temperature directly below and above the honeycomb catalyst. A schematic illustration of reactor setup is depicted in Figure 8.

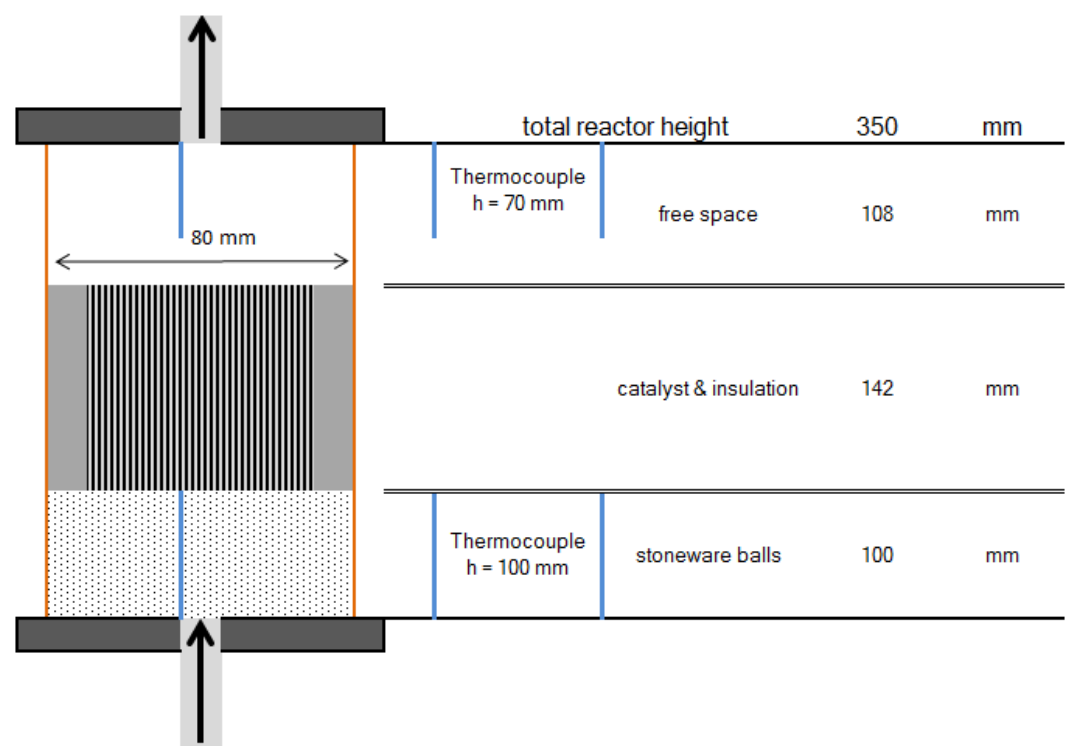

Figure 8. Schematic diagram of reactor setup.

For the present experiments, only two reactors were used. The process is designed for pressures up to 20 bar and maximum feed gas flow rates of $3 \mathrm{~m}^{3} / \mathrm{h}$ (STP). A simplified flow chart is shown in Figure 9. Reaction gases $\mathrm{H}_{2}$ (Hydrogen 5.0, purity 99.999\%, Linde Gas, Stadl-Paura, Austria) and $\mathrm{CO}_{2}$ (BIOGON ${ }^{\circledR}$ C, E290, purity 99.7\%, Linde Gas, Stadl-Paura, Austria) are charged from gas bottles via mass flow controllers and blended in a mixing chamber. Contrary to real plants, separation of trace components like $\mathrm{H}_{2} \mathrm{~S}$ or dust was not necessary. Next, the reaction gas is pre-heated in heat exchanger $\mathrm{W} 1$ to $>200{ }^{\circ} \mathrm{C}$ and fed into the first reactor R1. To ensure a minimum reaction temperature of $250{ }^{\circ} \mathrm{C}$, 
all reactors are equipped with electric trace heating systems. During operation, reactor temperatures are increasing due to the exothermicity of the reaction. Subsequently, the outlet gas of R1 is air cooled in a cooling coil to avoid temperature induced damage of valves and other equipment. The following reactor stage is similar to the first conversion step and consists of pre-heater W2, reactor R2 and a cooling coil. Finally, the produced gas is cooled and condensate is separated. A total number of four gas sampling points allows analysis of input and output gas composition of the particular reactor (infrared photometer URAS26 by ABB: $\mathrm{CO}, \mathrm{CO}_{2}, \mathrm{CH}_{4}$; thermal conductivity analyzer CALDOS27 by ABB: $\mathrm{H}_{2}$, Vienna, Austria; calibrated). For the combination of methanation plant and gas upgrading unit a connection point is included. Since the gas is flammable, it has to be combusted in a lab flare before feeding it into the exhaust gas system.

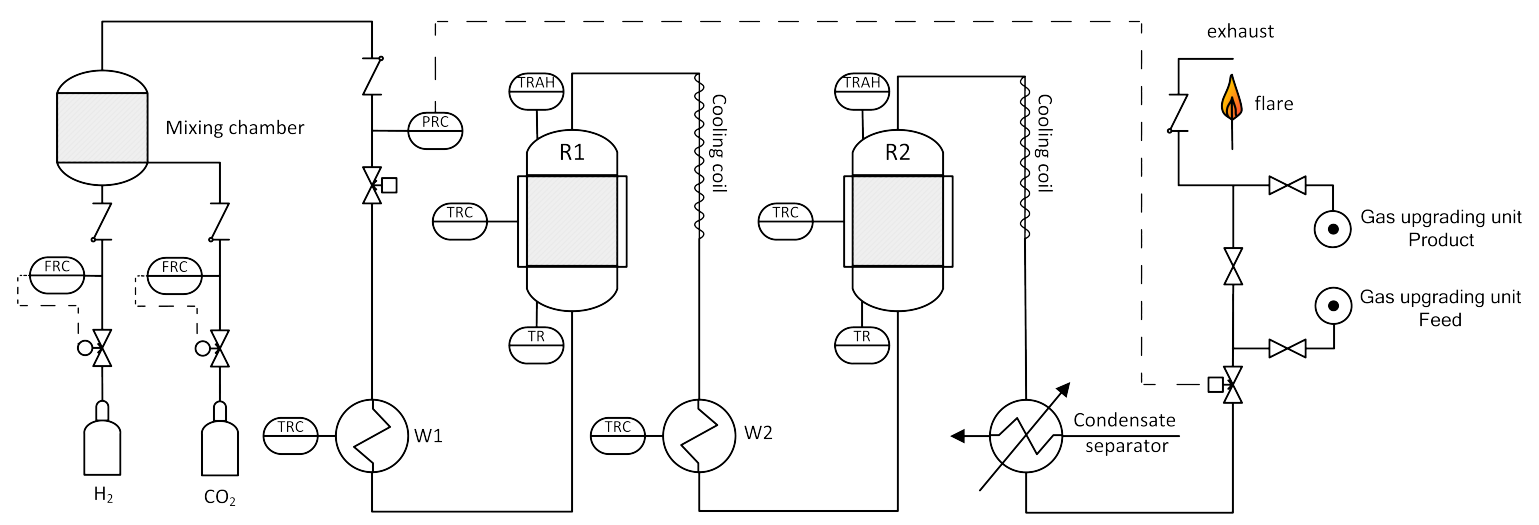

Figure 9. Simplified flow sheet of the lab scaled methanation plant.

\subsection{Membrane Gas Upgrading}

To assess the influence of the membrane based gas separation unit on the process, a lab-scaled demo plant was realized. The simplified flow sheet is depicted in Figure 10. The setup consists of a pulsation dampener, condenser, membrane unit and gas analysis. Gas from methanation enters and is fed into the pulsation dampener to prevent any damage to membranes or analytic equipment in case of unforeseen pressure changes. It is then dried at $4{ }^{\circ} \mathrm{C}$ to prevent condensation on the membrane surface. Two different polyimide membranes have been used to see the effects of module size and selectivity on product gas quality, $\mathrm{CH}_{4}$ recovery and stage cut. While both modules are polyimide based with similar outer dimensions, they vary in both permeance and selectivity. Ideal selectivities $\alpha_{i, j}$ and relative pure gas permeances $P$ for both modules are given in Table 3 . The selectivity of $\alpha_{\mathrm{CO}, \mathrm{CH}_{4}}$ was not determined for the applied modules, but literature indicates values in the range of 2.0 to 4.5 [31]. Hence, an efficient separation of $\mathrm{CO}$ and $\mathrm{CH}_{4}$ with polyimide membranes is not possible.

Table 3. Relative permeance and ideal selectivities for used membrane modules ${ }^{1}$.

\begin{tabular}{lccc}
\hline & Relative $\mathrm{CH}_{4}$ Permeance & $\alpha_{\mathbf{H}_{2}, \mathbf{C H}_{4}}$ & $\alpha_{\mathbf{C O}_{2}, \mathbf{C H}_{4}}$ \\
\hline Module 1 & 1 & 386.0 & 86.7 \\
Module 2 & 26.14 & 39.6 & 14.4 \\
\hline${ }^{1}$ Due to legal restrictions the exact permeances and membrane areas \\
can not be revealed.
\end{tabular}

The setup allows for separate use of each module or parallel use if an increased membrane area is needed, while only the former has been applied in current study. For each stream-feed from methanation, final product gas and off-gas-pressure, temperature, flow rate as well as concentration of $\mathrm{CH}_{4}, \mathrm{CO}_{2}, \mathrm{H}_{2}$ and $\mathrm{CO}$ are measured. Detection of the gaseous compounds (Gas Analyser GMS810 by SICK, Wiener Neudorf, Austria; calibrated) is done via infrared spectroscopy (Type: MULTOR) and heat conductivity (Type: THERMOR). All gas streams were then recombined and combusted. 
Operation for the membrane part is limited by pressure (16 bar) and process flow rates of up to $6 \mathrm{~m}^{3} / \mathrm{h}(\mathrm{STP})$.

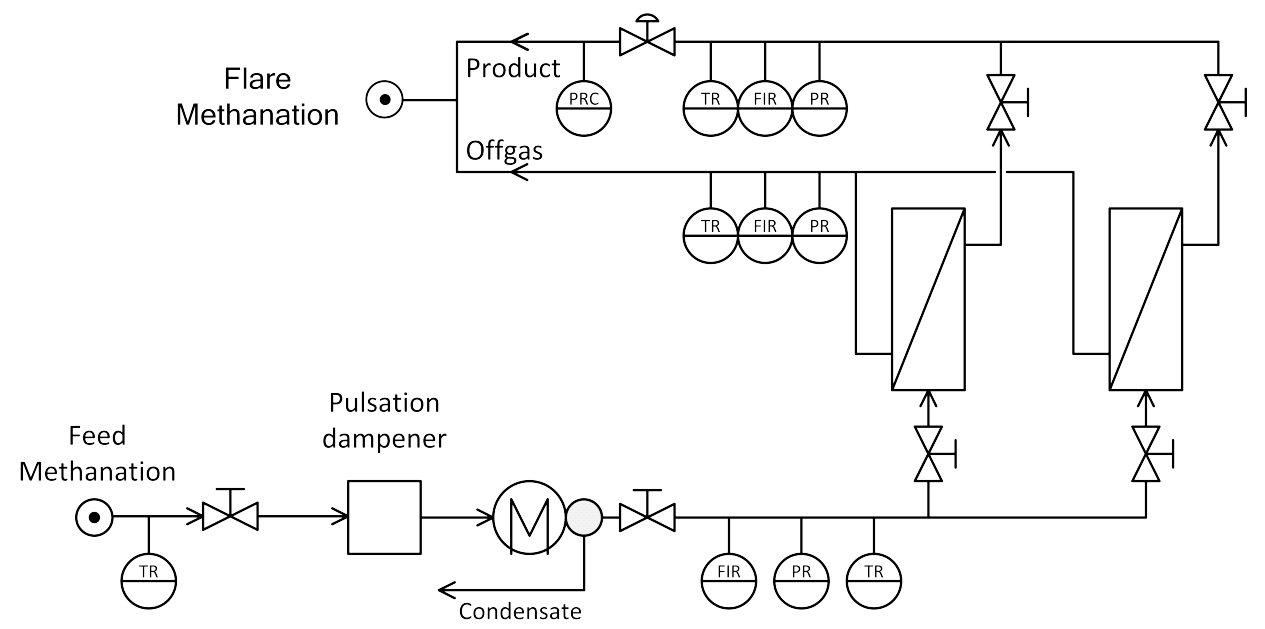

Figure 10. Simplified flow sheet of the lab scaled membrane plant.

\subsection{Combined Process}

For the conducted experiments, both test plants were combined in series, and methanation followed by gas upgrading (Figure 11). To ensure comparable system pressures, a proportional valve at the end of the process was used to adjust and control pressure. Consequently, methanation and gas upgrading were operated at the same pressure level, as long as pressure losses are neglected. To avoid mixing effects during gas sampling, each process setting was kept between 60 (6 bar) and $120 \mathrm{~min}$ (14 bar). A similar setup was presented by the authors in [29], using commercial catalyst for methanation. The presented results are single run experiments, though half of the experiments were repeated to verify reproducibility. Due to the experimental setup, it is not possible to obtain consistent process conditions, since reactor temperature is influenced by duration of experiment, system pressure and catalytic activity. If measurements are repeated within short time periods during the actual experiments, the results are within measurement certainty. Hence, the monitored reproducibility is satisfying.

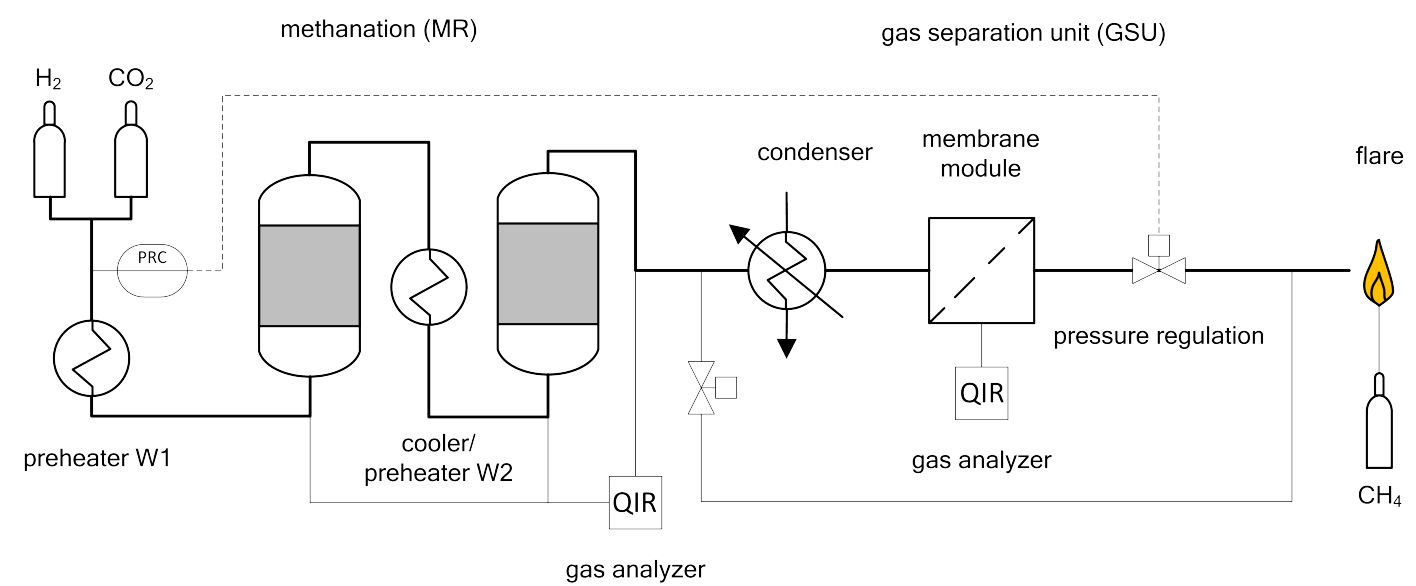

Figure 11. Basic flowsheet of the combined process methanation and gas separation unit. 


\section{Conclusions}

The presented concept, consisting of a methanation step, using newly developed honeycomb catalysts, and polyimide membrane gas upgrading, shows promising results for power to gas applications. Despite the early development stage of catalysts and lab scaled test plants a high quality SNG, in compliance with common natural gas network standards, can be produced. With further development of catalysts and optimized methanation operating conditions the conversion rate could be increased. Consequently, the decreased amount of $\mathrm{H}_{2}$ and $\mathrm{CO}_{2}$ is leading to an improved performance of the gas upgrading section. Regardless of methanation efficiency, membrane modules must be tailored to a fixed operating point or designed to handle varying conditions, either by parallelization or inclusion of a recycle loop, as results indicate high dependence between operating window and product gas quality.

\section{Patents}

Friedacher, A.; Biegger, P. Patenteinreichung: Anlage zur katalytischen Methanisierung, Aktenzeichen: A51029/2015, 01.12.2015. (translated: Friedacher, A.; Biegger, P. patent application: catalytic methanation process, reference number: A51029/2015, 01.12.2015.)

Author Contributions: P.B. and F.K. conceived and designed the experiments; P.B., F.K., A.R.M. and M.M. performed the experiments; All authors analyzed the data; P.B. and F.K. wrote the paper.

Funding: This research was funded by Austrian Research Promotion Agency FFG grant number 839172.

Acknowledgments: The experiments of this work were conducted as part of the research project: "Research Studio Austria: EE-Methan aus $\mathrm{CO}_{2}$-Entwicklung eines katalytischen Verfahrens zur Methanisierung von $\mathrm{CO}_{2}$ aus industriellen Quellen" (translated: Renewable Methane from $\mathrm{CO}_{2}$-Development of a catalytic methanation process of $\mathrm{CO}_{2}$ from industrial sources), funded by the Austrian Research Promotion Agency FFG. Besides the Montanuniversität Leoben and University of Technology Vienna, the Energieinstitut at Johannes Kepler University Linz and Profactor GmbH were involved, with the industrial partners Christof Industries GmbH, OMV AG, EVN $\mathrm{AG}$ and Repotec $\mathrm{GmbH}$. The authors also would like to acknowledge the work of Christian Santner during his bachelor's studies.

Conflicts of Interest: The authors declare no conflict of interest. The founding sponsors had no role in the design of the study, in the collection, analyses, or interpretation of data, in the writing of the manuscript, and in the decision to publish the results.

\section{Abbreviations}

The following abbreviations are used in this manuscript:

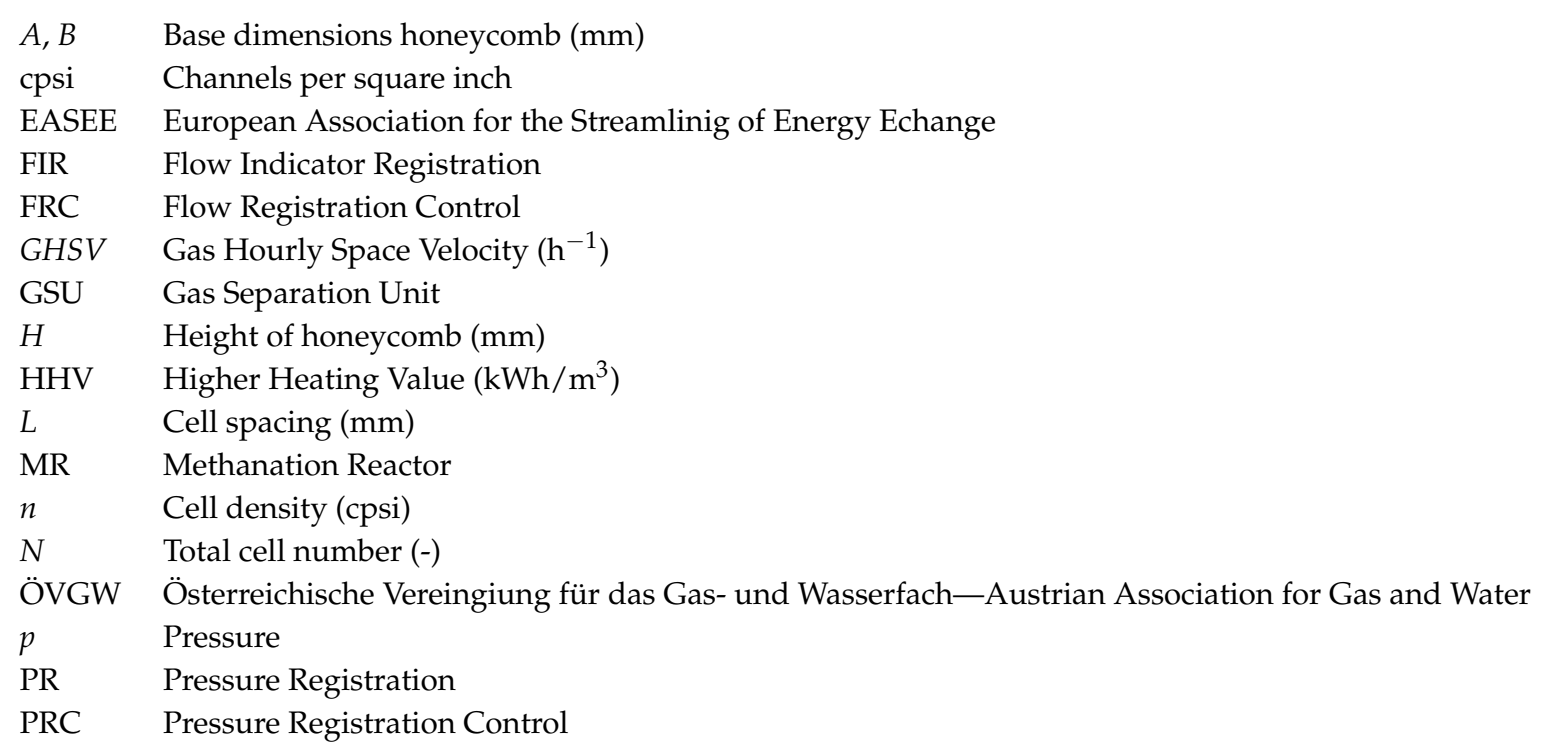




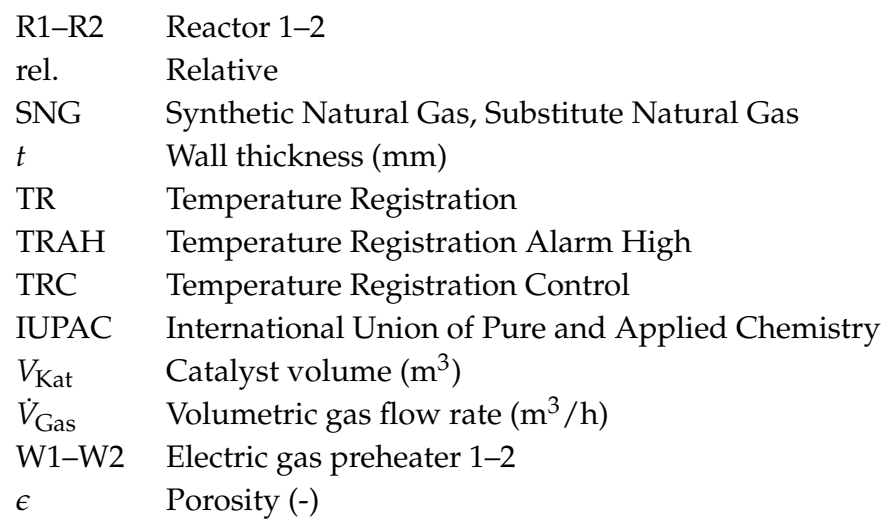

\section{References}

1. Sterner, M.; Stadler, I. Energiespeicher-Bedarf, Technologien, Integration; Springer: Berlin/Heidelberg, Germany, 2014.

2. Bajohr, S.; Götz, M.; Graf, F.; Ortloff, F. Speicherung von regenerativ erzeugter elektrischer Energie in der Erdgasinfrastruktur. gwf-Erdgas 2011, 152, 200-210.

3. Farrenkopf, M. Koks: Die Geschichte Eines Wertstoffes; Schriften des Bergbau-Archivs; Selbstverl. des Deutschen Bergbau-Museums: Bochum, Germany, 2003; Volume 12.

4. Österreichische Vereinigung für das Gas-und Wasserfach. Erdgas in Österreich—Gasbeschaffenheit Richtlinie G 31; Österreichische Vereinigung für das Gas-undWasserfach: Wien, Austria, 2001.

5. Leicher, J.; Giese, A.; Burger, N. (Eds.) Gasqualitäten im veränderten Energiemarkt: Herausforderungen und Chancen für die Häusliche, Gewerbliche und Industrielle Anwendung; Edition gwf-Gas, Erdgas, DIV: München, Germany, 2014.

6. EASEE-Gas. Common Business Practice. Avaliable online: https://easee-gas.eu/what-are-the-cbps (accessed on 6 November 2008).

7. Dace, E.; Rusanova, J.; Gusca, J.; Blumberga, D. Selecting a Catalyst for Methanation Process: Technical and Economic Performance Based TOPSIS Analysis. In Proceedings of the 27th International Conference on Efficiency, Cost, Optimization, Simulation and Environmental Impact of Energy Systems (ECOS 2014), Turku, Finland, 15-19 June 2014; Volume 1.

8. Lehner, M. Power-to-Gas: Technology and Business Models; Springer Briefs in Energy; Springer: Cham, Switzerland; Heidelberg, Germany, 2014.

9. Kopyscinski, J.; Schildhauer, T.J.; Biollaz, S.M.A. Production of synthetic natural gas (SNG) from coal and dry biomass-A technology review from 1950 to 2009. Fuel 2010, 89, 1763-1783, doi:10.1016/j.fuel.2010.01.027. [CrossRef]

10. Rönsch, S.; Schneider, J.; Matthischke, S.; Schlüter, M.; Götz, M.; Lefebvre, J.; Prabhakaran, P.; Bajohr, S. Review on methanation-From fundamentals to current projects. Fuel 2016, 166, 276-296, doi:10.1016/j.fuel.2015.10.111. [CrossRef]

11. Niesner, J.; Jecha, D.; Stehlík, P. Biogas upgrading technologies: State of art review in European region. Chem. Eng. Trans. 2013, 35, 517-522.

12. Muñoz, R.; Meier, L.; Diaz, I.; Jeison, D. A review on the state-of-the-art of physical/chemical and biological technologies for biogas upgrading. Rev. Environ. Sci. Bio/Technol. 2015, 14, 727-759, doi:10.1007/s11157-015-9379-1. [CrossRef]

13. Miltner, M.; Makaruk, A.; Harasek, M. Review on available biogas upgrading technologies and innovations towards advanced solutions. J. Clean. Prod. 2017, 161, 1329-1337, doi:10.1016/j.jclepro.2017.06.045. [CrossRef]

14. Sun, Q.; Li, H.; Yan, J.; Liu, L.; Yu, Z.; Yu, X. Selection of appropriate biogas upgrading technology-a review of biogas cleaning, upgrading and utilisation. Renew. Sustain. Energy Rev. 2015, 51, 521-532, doi:10.1016/j.rser.2015.06.029. [CrossRef]

15. Collet, P.; Flottes, E.; Favre, A.; Raynal, L.; Pierre, H.; Capela, S.; Peregrina, C. Techno-economic and Life Cycle Assessment of methane production via biogas upgrading and power to gas technology. Appl. Energy 2017, 192, 282-295, doi:10.1016/j.apenergy.2016.08.181. [CrossRef] 
16. Andriani, D.; Wresta, A.; Atmaja, T.D.; Saepudin, A. A Review on Optimization Production and Upgrading Biogas Through $\mathrm{CO}_{2}$ Removal Using Various Techniques. Appl. Biochem. Biotechnol. 2014, 172, 1909-1928, doi:10.1007/s12010-013-0652-x. [CrossRef] [PubMed]

17. Scholz, M.; Melin, T.; Wessling, M. Transforming biogas into biomethane using membrane technology. Renew. Sustain. Energy Rev. 2013, 17, 199-212, doi:10.1016/j.rser.2012.08.009. [CrossRef]

18. Miltner, M.; Makarukb, A.; Haraseka, M. Selected Methods of Advanced Biogas Upgrading. Chem. Eng. Trans. 2016, 52, 463-468.

19. Weitkamp, J.; Gläser, R. Methodische Grundlagen: Katalyse. In Winnacker-Küchler: Chemische Technik; Dittmeyer, R., Keim, W., Kreysa, G., Oberholz, A., Eds.; Wiley-VCH Verlag GmbH \& Co. KGaA: Weinheim, Germany, 2004; Volume 1.

20. Manfe, M.M.; Kulkarni, K.S.; Kulkarni, A.D. Industrial Application of Monolith Catalysts/Reactors. Int. J. Adv. Eng. Res. Stud. 2011, 1, 1-3.

21. Cybulski, A.; Moulijn, J.A. Structured Catalysts and Reactors. In Chemical Industries, 2nd ed.; Taylor \& Francis: Boca Raton, FL, USA, 2006; Volume 110.

22. Froment, G.F.; Bischoff, K.B.; de Wilde, J. Chemical Reactor Analysis and Design, 3rd ed.; Wiley: Hoboken, NJ, USA, 2011.

23. Friedacher, A.; Biegger, P. Patenteinreichung: Anlage zur Katalytischen Methanisierung. Aktenzeichen: A51029/2015, 1 December 2015

24. Makaruk, A.; Miltner, M.; Harasek, M. Membrane biogas upgrading processes for the production of natural gas substitute. Sep. Purif. Technol. 2010, 74, 83-92, doi:10.1016/j.seppur.2010.05.010. [CrossRef]

25. Basu, S.; Khan, A.L.; Cano-Odena, A.; Liu, C.; Vankelecom, I.F.J. Membrane-based technologies for biogas separations. Chem. Soc. Rev. 2010, 39, 750-768, doi:10.1039/B817050A. [CrossRef] [PubMed]

26. Biegger, P.; Medved, A.R.; Lehner, M.; Ebner, H.M.; Friedacher, A. Methanisierung im Umfeld von dqPower to Gasdq. In Kurzfassungsband zum 14. Symposium Energieinnovation; Institut für Elektrizitätswirtschaft und Energieinnovation, TU Graz., Ed.; Verlag der Technischen Universität Graz: Graz, Austria, 2016; pp. $463-464$.

27. Biegger, P.; Medved, A.R.; Lehner, M. Vergleich der Trägermaterialien $\mathrm{y}-\mathrm{Al}_{2} \mathrm{O}_{3}$ und $\mathrm{t}-\mathrm{ZrO}_{2}$ in der katalytischen Methanisierung von $\mathrm{CO}_{2}$. In 12th Minisymposium Verfahrenstechnik; Hirn, U., Ed.; Verlag der Technischen Universität Graz: Graz, Austria, 2016; pp. 27-30.

28. Biegger, P.; Medved, A.R.; Lehner, M. Lastflexible Methanisierung als Teil der Power-to-Gas Prozesskette. In Forum Econogy 2016; Energieinstitut an der Johannes Kepler Universität Linz: Linz, Austria, 2016.

29. Kirchbacher, F.; Biegger, P.; Miltner, M.; Lehner, M.; Harasek, M. A new methanation and membrane based power-to-gas process for the direct integration of raw biogas-Feasability and comparison. Energy 2018, 146, 34-46, doi:10.1016/j.energy.2017.05.026. [CrossRef]

30. Fuchsbauer, A.; Dittert, B.; Außerhuber, H.; Leichtfried, H. Endbericht des geförderten Projektes: EE-Methan aus $\mathrm{CO}_{2}$ : Interner Forschungsbericht.

31. Tanaka, K.; Kita, H.; Okano, M.; Okamoto, K.I. Permeability and permselectivity of gases in fluorinated and non-fluorinated polyimides. Polymer 1992, 33, 585-592, doi:10.1016/0032-3861(92)90736-G. [CrossRef]

(C) 2018 by the authors. Licensee MDPI, Basel, Switzerland. This article is an open access article distributed under the terms and conditions of the Creative Commons Attribution (CC BY) license (http:// creativecommons.org/licenses/by/4.0/). 